\title{
Digital Accounting for Small to Medium Enterprises Using Mobile Applications
}

\author{
Andhita Yukihana Rahmayanti ${ }^{1 *}$, Devie Rahmawati ${ }^{2}$ \\ ${ }^{1}$ Accounting and Audit Laboratory, Vocational Education Program, Universitas Indonesia \\ ${ }^{2}$ Public Relations Laboratory, Vocational Education Program, Universitas Indonesia \\ *Email: a.yukihana@vokasi.ui.ac.id
}

\begin{abstract}
Small and medium entrepreneurs need mobile accounting applications that can be used to create financial reports to review the financial condition of their businesses. Existing accounting applications are now widely used by small and medium entrepreneurs. In this study, the effectiveness of mobile accounting applications was analyzed. Effective mobile applications should be easy for small and medium entrepreneurs to use for creating financial reports in accordance with accounting standards, and the financial statements generated must be easy for business owners to use.
\end{abstract}

Keywords: mobile accounting applications, digital accounting, small medium enterprises (SME)

\section{Introduction}

Internet-based economy and mobile apps are already widely used by small businesses. The advantage of mobile applications is that small- and medium-sized entrepreneurs (SME) are able to save large amounts of money by using only these applications rather than by investing in information technology (IT) infrastructure. Mobile-based accounting applications are a type of mobile application used by small and medium entrepreneurs.. Technological developments have changed the way accountants and other users of financial statements carry out accounting activities and record financial transactions (Güney, 2014). Accounting professionals now face new challenges generated by digital services, artificial intelligence, cybercrime, and new technologies that are changing accounting activities (Stanciua, 2017). The accounting profession is on the brink of change, and many practitioners do not have sufficient skills in emerging technologies.

Accountants need to develop new skills in order to work effectively and efficiently with new technologies such as cloud platforms, big data, data analysis, and mobile technology. To a large extent, artificial intelligence and process automation have taken over accountants' professional duties. This can create more complex activities for accountants, such as business analysis and advising (Rîndaşu, 2017). The accounting professionals can be as an assistant in providing to accounting innovation. Mobile technology can be used to improve the process of accounting recording for small and medium entrepreneurs. For example, cloud accounting technology is one successful solution derived from cloud computing that enables the storage and processing of corporate financial and accounting documents in the cloud (Tudoran \& Ionescu, 2014). This initiative is likely to appeal to SMEs that want to provide information to customers (Bankosz \& Kerins, 2014). Mobile accounting applications are easy for SMEs to use. However, the effectiveness of existing accounting applications needs to be analyzed.

\section{Literature Review}

With the development of small and medium enterprises, there are some new accounting services, one of which is bookkeeping. But the bookkeeping has also its disadvantages. To solve the problem of many ignored questions of bookkeeping, the method of searching for countermeasures is given in this paper (Li, 2013). Smartphone applications are important tools for business consumers, and the increasing number of mobile devices developed for the business and accounting fields are greatly appreciated (Güney, 2014).

The accounting system is used to measure financial performance by recording and classifying all transactions such as sales, purchases, operating expenses, assets, and liabilities in accord with generally accepted accounting principles. Standard formatting of financial statements allows evaluations of past and present performance and comparison with future prospects. Accounting can be defined as recording, classifying, and summarizing transactions or financial information into financial statements for internal and external use. IT has changed the 
way financial statements are made. Financial statements can be easily made on a mobile phone in accordance with accepted principles. In addition, these statements can be made without special training. However, the mobile application should track financial transactions accurately in the preparation of financial statements.

Changes in technological developments that require significant financial reporting can be made easily and quickly so that users of financial statements can make decisions quickly. There are several important factors that should be considered when selecting an accounting system to create financial statements (Ghasemi, Shafeiepour, Aslani, \& Barvayeh, 2011).

\subsection{Levels of Functionality}

The accounting application requires a high level of functionality with which it can produce financial statements in compliance with the generally accepted account principles. The software should be able to produce statements of financial position, income statements, statements of change in equity, and cash flow statements. However, at a minimum the application is required to present a financial report that consists of a statement of financial position and an income statement that users can access easily. In addition, mobile applications must be able to save data to the cloud or be able to convert data into a spreadsheet or word processing application.

\subsection{Level of Accuracy}

The digital accounting system should be highly accurate before the financial statements can be prepared. The computerized system should post the journal entries and ensure that every transaction is recorded correctly. This accuracy reduces the number of accountants needed to process financial statements. However, qualified supervisors are required to analyze the financial reports that are compiled by the mobile apps.

\subsection{Processing Speed}

Timeliness of the app is of importance when presenting financial statements for the decision-making process of its users. By using mobile accounting applications, accountants can quickly process financial information. The faster the processing of financial statements for overall transactions or for individual transactions occurs, the more the time required to close the accounting period is reduced. This saves work hours and labor costs. This can shorten the monthly or yearly accounting period closing processes, especially when preparing taxes. This can help companies control cost, thereby improving efficiency as a whole.

\subsection{External Reporting}

The financial reports generated for both investors and stakeholders can be enhanced by using a computerized accounting system. Mobile accounting applications are especially advantageous in that they can be used anytime and anywhere. Improving the level of reporting quality allows users of financial statements to make faster decisions about whether a company is financially stable, whether it has opportunities for company growth, and whether the company has the potential to become a high-value company.

Today's accountants must be familiar with the software or mobile applications to help them perform accounting functions more effectively and efficiently. One application is expected to cover all required accounting functions. The features present, which are needed and viewed by users of mobile accounting applications, can share the invoices to do the billings, can store the customer database, can manage inventory, and can help calculate the tax. The features considered when choosing an accounting application include the following:

- Word processing. Accountants need a word processor to prepare reports, bills, memos, and financial reports.

- Graphics processing. Although not specifically required in preparing financial statements, it is usually necessary to install company logos or images in the invoices and display reports or graphic images of data like charts on reports.

- Image processing. Image processing is required to capture electronic images of data so that they can be stored and shared. With the help of document imagery, accountants can scan paper documents to a computer and process these files electronically. Companies that use document image processing can move toward a paperless office.

- Electronic data exchange. Electronic data exchange (EDI) is required by companies to communicate electronically. EDI allows companies to exchange documents electronically with each other. For 
example, buyers and suppliers exchange purchase orders and invoices electronically in the form of images.

- Electronic funds transfer. With electronic funds transfer (EFT), the company can connect to the bank. The EFT system allows companies to make payments and collect electronically. In this case, the company can pay the debt to the supplier. In addition, whenever a company makes a sale, the transaction will be directly charged to a consumer bank account and simultaneously credited to the company account. In addition, all relevant accounts such as receivables and cash are updated immediately by the computerized system. The use of computerized systems mentioned above has led to automation of digital accounting information systems.

Another way that is usually considered when choosing a mobile accounting application is to look for a basic program that enables SME business owners or managers who do not understand accounting to complete traditional accounting functions without much formal training or technical knowledge. Business owners may also transfer this information electronically to a public accountant for audit or tax purposes. Information can be transferred more accurately and in a timelier manner electronically than by submitting a stack of manual accounting ledgers.

\section{Methodology}

High technology and high mobility have forced people to communicate, entertain, and work through existing applications on their mobile phones. Mobile applications are important factors in modern life. For this research, a qualitative approach based on individual experiences was chosen to obtain information on accounting applications. Research surveys were adapted from previous literature and personal knowledge about accounting and mobile accounting applications. The survey was conducted on eight mobile applications that can be installed on Android-based mobile phones. Table 1 lists the accounting applications surveyed in this research.

Table 1. Developers of mobile accounting apps

\begin{tabular}{|c|c|c|c|c|c|c|}
\hline $\begin{array}{c}\mathrm{N} \\
\mathrm{O}\end{array}$ & $\begin{array}{l}\text { Accounting } \\
\text { Mobile } \\
\text { Applications }\end{array}$ & Developer & Developer Country & $\begin{array}{c}\text { Capacity } \\
\text { (MB) }\end{array}$ & Release on & Downloader \\
\hline 1 & $\begin{array}{l}\text { Golden } \\
\text { Business } \\
\text { Accounting }\end{array}$ & $\begin{array}{c}\text { Golden } \\
\text { Accounting }\end{array}$ & Germany & 9,05 & $\begin{array}{c}\text { June } 16, \\
2017\end{array}$ & $>100.000$ \\
\hline 2 & $\begin{array}{l}\text { Zoho Book } \\
\text { Accounting }\end{array}$ & $\begin{array}{c}\text { Zoho } \\
\text { Corporation }\end{array}$ & USA & 5,61 & $\begin{array}{c}\text { January 3, } \\
2014\end{array}$ & $>100.000$ \\
\hline 3 & $\begin{array}{l}\text { Xero } \\
\text { Accounting } \\
\text { Software }\end{array}$ & $\begin{array}{c}\text { Xero } \\
\text { Accounting }\end{array}$ & New Zealand & 7,3 & $\begin{array}{l}\text { October 1, } \\
2012\end{array}$ & $>100.000$ \\
\hline 4 & $\begin{array}{l}\text { Simple } \\
\text { Accounting }\end{array}$ & $\begin{array}{l}\text { ADSL } \\
\text { Infotech }\end{array}$ & India & 7,28 & $\begin{array}{l}\text { September } \\
26,2015\end{array}$ & $>50.000$ \\
\hline 5 & $\begin{array}{l}\text { Small Business } \\
\text { Accounting Pro }\end{array}$ & $\begin{array}{c}\text { TheBusiness } \\
\text { Soft }\end{array}$ & Australia & 9,07 & $\begin{array}{c}\text { November } \\
28,2013\end{array}$ & $>100.000$ \\
\hline 6 & Paper.id & Paper.Id & Indonesia & 6,53 & $\begin{array}{c}\text { January } 29, \\
2018\end{array}$ & $>1.000$ \\
\hline 7 & $\begin{array}{ll}\text { Zahir } & \text { Simply } \\
\text { Online } & \\
\end{array}$ & $\begin{array}{c}\text { Zahir } \\
\text { Internasional } \\
\end{array}$ & Indonesia & 10,79 & $\begin{array}{c}\text { January 26, } \\
2018 \\
\end{array}$ & $>10.000$ \\
\hline 8 & $\begin{array}{l}\text { Akuntansi } \\
\text { UKM }\end{array}$ & WiinFeel & Indonesia & 8,6 & $\begin{array}{c}\text { December 9, } \\
2014\end{array}$ & $>100.000$ \\
\hline
\end{tabular}

Because this is an exploratory study, this research investigates the use of mobile accounting applications from the results of user reviews. The survey results were divided into two tables. Table 2 describes the user satisfaction, and Table 3 designates a rating score of 1-4 for each mobile app feature. Fifteen features were surveyed. The features were as follows: low cost, ease of use, customer service, accountant access, timesaving features, reporting capabilities, integration with third-party apps, mobile access and mobile features, no service limitations (including the number of customers, invoices, users, and transaction packages allowed), additional service like credit card processing, tax preparation and payroll services, capacity, applicable to SME, management inventory, invoicing, and no advertising. 


\section{Results and Discussion}

This study focuses on the use of mobile accounting applications on Android phones. Table 2 records the user satisfaction for each phone as indicated by the star rating level. According to the data in Table 2, the "Zahir Simply Online" accounting application has the highest level of satisfaction among users of accounting applications in Indonesia at $87.32 \%$ (5 stars), while "Xero Accounting Software" has the lowest level of satisfaction, with $18.07 \%$ (1 star). This indicates that people prefer Zahir Simply Online when compared with other applications. Zahir Simply Online offers the first month free, after that customers must pay IDR 99.000 per month.

Table 2. Level of customer satisfaction

\begin{tabular}{|c|l|c|c|c|c|c|}
\hline $\begin{array}{c}\text { N } \\
\text { o }\end{array}$ & Accounting Mobile Applications & Star 5 & Star 4 & Star 3 & Star 2 & Star 1 \\
\hline 1 & Golden Business Accounting & $76,87 \%$ & $11,81 \%$ & $4,34 \%$ & $1,69 \%$ & $5,30 \%$ \\
\hline 2 & Zoho Book Accounting & $67,69 \%$ & $22,39 \%$ & $5,50 \%$ & $1,46 \%$ & $2,96 \%$ \\
\hline 3 & Xero Accounting Software & $41,90 \%$ & $17,16 \%$ & $13,04 \%$ & $9,83 \%$ & $18,07 \%$ \\
\hline 4 & Simple Accounting & $70,21 \%$ & $15,47 \%$ & $5,80 \%$ & $2,13 \%$ & $6,38 \%$ \\
\hline 5 & Small Business Accounting Pro & $57,35 \%$ & $18,88 \%$ & $9,89 \%$ & $3,99 \%$ & $9,89 \%$ \\
\hline 6 & Paper.id & $82,05 \%$ & $5,13 \%$ & $5,13 \%$ & $0,00 \%$ & $7,69 \%$ \\
\hline 7 & Zahir Simply Online & $87,32 \%$ & $4,23 \%$ & $5,63 \%$ & $1,41 \%$ & $1,41 \%$ \\
\hline 8 & Akuntansi UKM & $66,53 \%$ & $20,31 \%$ & $9,80 \%$ & $2,05 \%$ & $1,30 \%$ \\
\hline
\end{tabular}

Table 3 uses a rating score of 1-4 for each listed mobile app feature. The total scores in Table 3 show Small Business Accounting Pro with the highest score (56). "Zoho Book Accounting" received the second highest score (53), while "Simple Accounting" scored lowest (40). The scoring data indicates that Zahir Simply Online was the only app to receive a score of 1 on low cost, but it may still be an option for the needs of the accounting community because it received a score of 4 in several other categories. This means that Zahir Simply Online can be a solution for the needs of accountants. A comparison of the two tables indicates that "Small Business Accounting Pro" is an accounting application that has the best features required by users; however, the app received a 5-star rating from only $57.35 \%$ of users in Table 2, which indicates that users are not quite satisfied with the application. On the other hand, Simple Accounting does not have the features required by customers according to Table 3 , but $70.21 \%$ of the users are quite satisfied with the application.

Table 3. Application feature rating

\begin{tabular}{|c|c|c|c|c|c|c|c|c|c|}
\hline $\begin{array}{c}\mathrm{N} \\
\mathrm{o}\end{array}$ & $\begin{array}{c}\text { Features } \\
\text { Category }\end{array}$ & $\begin{array}{c}\text { Golden } \\
\text { Business } \\
\text { Accounti } \\
\mathrm{ng}\end{array}$ & $\begin{array}{c}\text { Zoho } \\
\text { Book } \\
\text { Accounti } \\
\mathrm{ng}\end{array}$ & $\begin{array}{c}\text { Xero } \\
\text { Accounti } \\
\text { ng } \\
\text { Software }\end{array}$ & $\begin{array}{c}\text { Simple } \\
\text { Accounti } \\
\text { ng }\end{array}$ & $\begin{array}{c}\text { Small } \\
\text { Business } \\
\text { Accounti } \\
\text { ng Pro }\end{array}$ & $\begin{array}{c}\text { Paper.i } \\
\mathrm{d}\end{array}$ & $\begin{array}{c}\text { Simpl } \\
\text { y } \\
\text { Onlin } \\
\text { e }\end{array}$ & $\begin{array}{c}\text { Akuntan } \\
\text { si UKM }\end{array}$ \\
\hline 1 & Low Cost & 2 & 2 & 2 & 3 & 2 & 4 & 1 & 3 \\
\hline 2 & Ease of use & 3 & 4 & 4 & 4 & 3 & 4 & 4 & 3 \\
\hline 3 & $\begin{array}{c}\text { Customer } \\
\text { service }\end{array}$ & 2 & 4 & 3 & 2 & 4 & 2 & 4 & 2 \\
\hline 4 & $\begin{array}{c}\text { Accountant } \\
\text { access }\end{array}$ & 4 & 4 & 2 & 2 & 4 & 2 & 4 & 4 \\
\hline 5 & $\begin{array}{c}\text { Timesavin } \\
\text { g features }\end{array}$ & 3 & 4 & 2 & 2 & 4 & 4 & 4 & 4 \\
\hline 6 & $\begin{array}{c}\text { Reporting } \\
\text { capabilities }\end{array}$ & 4 & 4 & 1 & 2 & 4 & 2 & 2 & 4 \\
\hline 7 & $\begin{array}{c}\text { Integration } \\
\text { with third- } \\
\text { party apps }\end{array}$ & 2 & 2 & 3 & 4 & 4 & 1 & 4 & 4 \\
\hline 8 & $\begin{array}{c}\text { Mobile } \\
\text { access and } \\
\text { mobile } \\
\text { features }\end{array}$ & 4 & 4 & 3 & 4 & 4 & 2 & 2 & 4 \\
\hline 9
\end{tabular}




\begin{tabular}{|c|c|c|c|c|c|c|c|c|c|}
\hline $\begin{array}{l}\mathrm{N} \\
\mathrm{o}\end{array}$ & $\begin{array}{l}\text { Features } \\
\text { Category }\end{array}$ & $\begin{array}{c}\text { Golden } \\
\text { Business } \\
\text { Accounti } \\
\text { ng }\end{array}$ & $\begin{array}{c}\text { Zoho } \\
\text { Book } \\
\text { Accounti } \\
\text { ng }\end{array}$ & $\begin{array}{c}\text { Xero } \\
\text { Accounti } \\
\text { ng } \\
\text { Software }\end{array}$ & $\begin{array}{c}\text { Simple } \\
\text { Accounti } \\
\text { ng }\end{array}$ & $\begin{array}{c}\text { Small } \\
\text { Business } \\
\text { Accounti } \\
\text { ng Pro }\end{array}$ & $\begin{array}{l}\text { Paper.i } \\
\quad \text { d }\end{array}$ & $\begin{array}{c}\text { Zahir } \\
\text { Simpl } \\
\text { y } \\
\text { Onlin } \\
\text { e }\end{array}$ & $\begin{array}{l}\text { Akuntan } \\
\text { si UKM }\end{array}$ \\
\hline & $\begin{array}{l}\text { including } \\
\text { the number } \\
\text { of } \\
\text { customers, } \\
\text { invoices, } \\
\text { users, and } \\
\text { transaction } \\
\text { s packages } \\
\text { allow }\end{array}$ & & & & & & & & \\
\hline 10 & $\begin{array}{c}\text { Additional } \\
\text { services } \\
\text { like credit } \\
\text { card } \\
\text { processing, } \\
\text { tax } \\
\text { preparation } \\
\text { and payroll } \\
\text { services }\end{array}$ & 4 & 3 & 3 & 2 & 4 & 1 & 2 & 2 \\
\hline 11 & Capacity & 3 & 4 & 3 & 3 & 3 & 4 & 2 & 3 \\
\hline 12 & $\begin{array}{c}\text { Applicable } \\
\text { to SME }\end{array}$ & 2 & 4 & 4 & 4 & 4 & 4 & 4 & 4 \\
\hline 13 & $\begin{array}{c}\text { Manageme } \\
\text { nt } \\
\text { Inventory }\end{array}$ & 4 & 2 & 1 & 2 & 4 & 2 & 2 & 2 \\
\hline 14 & Invoicing & 4 & 4 & 4 & 2 & 4 & 4 & 4 & 2 \\
\hline 15 & $\begin{array}{c}\text { No } \\
\text { Contains } \\
\text { Advertisin } \\
\text { g }\end{array}$ & 4 & 4 & 4 & 2 & 4 & 4 & 4 & 4 \\
\hline & & 47 & 53 & 42 & 40 & 56 & 42 & 47 & 47 \\
\hline
\end{tabular}

\section{Conclusion}

Overall, the mobile accounting application that has the most features customers need is Small Business Accounting Pro, but this app does not provide high satisfaction to its customers. An accounting application that does give high satisfaction to its users is Zahir Simply Online, although its features are not outstanding.

\section{References}

Bankosz, G. S. \& Kerins, J. (2014). Mobile technology-enhanced asset maintenance in an SME. Journal of Quality in Maintenance Engineering, 20,163-181.

Ghasemi, M., Shafeiepour, V., Aslani, M., \& Barvayeh, E. (2011). The impact of information technology (it) on modern accounting systems. in Procedia-Social and Behavioral Sciences, 28,112-116.

Güney, A. (2014). Role of technology in accounting and e-accounting. Procedia-Social and Behavioral Sciences, 152, 852855.

Li, Q. (2013). Study of bookkeeping in the small and medium-sized enterprise. In Z. Yin, L. Pan, X. Fang (Eds.), Proceedings of The Eighth International Conference on Bio-Inspired Computing: Theories and Applications (BICTA), 2013. Advances in Intelligent Systems and Computing, vol 212. Springer, Berlin, Heidelberg.

Rîndaşu, S. (2017). Emerging information technologies in accounting and related security risks-what is the impact on the Romanian accounting profession. Accounting and Management Information Systems, 16(4), 581-609.

Stanciu, V. \& Gheorghe, M. (2017). An exploration of the accounting profession-the stream of mobile device. Accounting and Management Information Systems, 16(3), 369-385.

Tudoran, L. E. \& Ionescu, B. S. (2014). The use of accounting apps via mobile cloud computing in Romania. Annales Universitatis Apulensis : Series Oeconomica, 16, 294-303. 